DOI: $10.17951 /$ lrp.2021.40.4.111-127

\author{
KATARZYNA KLIMKOWSKA \\ Maria Curie-Skłodowska University, Lublin, Poland \\ ORCID - 0000-0001-6388-274X
}

\title{
SOLUTION-FOCUSED APPROACH AS A MEANS OF ENHANCING TEACHER PROFESSIONALISM
}

Introduction: Teachers' development programmes focus on the achievement of profession-related and pedagogical competence, as well as on the shaping of professional conduct and culture. Teachers' work and their personal and professional goals are affected by how they perceive themselves as persons and as professionals, and also by how they see their students and the teaching environment.

Research Aim: This article aims to present the solution-focused approach (SFA) philosophy and explore its implications for the growth of teachers' professionalism, irrespective of its national or international contexts. The article unveils how to use SFA to make it advantageous for teachers' professional growth. The article explores the following topics:

1. SFA as a worldview and a methodology of explaining human experience useful for building developmental relations.

2. SFA as an inventory of educational and developmental techniques useful for contemporary classrooms.

3. SFA as an inventory of self-development activities in constructing teachers' life and professional success.

Evidence-based Facts: Professionalism of the teachers is approached from different perspectives - as highly qualified professionals, as a set of given attitudes towards all participants of the education process, or as a space for teachers' professional growth that relates to development and mastering the profession. The main aim of the SFA is looking for solutions in the preferred/ desired future, which allows one to find solutions to a present problem.

Summary: Solution-focused approach is a tool that can be used to empower the acquisition of personal and professional competences by teachers. It can enrich university curricula and teacher training programmes.

Keywords: teacher professionalism, solution-focused approach, building solutions, problem solving 


\section{INTRODUCTION}

Teachers' development programmes focus on the achievement of profession-related and pedagogical competence, as well as on the shaping of professional conduct and culture. Teachers' work and their personal and professional goals are affected by how they perceive themselves as persons and as professionals, and also by how they see their students and the teaching environment.

It is important to look for new ways of professional development for teachers. One such proposal is the adaptation of the solution-focused approach (SFA) to education. This approach grew out of psychotherapy, but applying its philosophy to the teacher's work enhances the quality of educational interventions (Mahlberg, Sjoblom, 2004). In Poland, it is only in the last decade that proposals have been made to encourage teachers to use SFA in their work (Zubrzycka-Maciąg, 2019; Majchrowska, Zubrzycka-Maciąg, 2016).

\section{RESEARCH AIM}

This article aims to present SFA philosophy and explore its implications for the growth of teachers' professionalism, irrespective of its national or international contexts. The article unveils how to use SFA to make it advantageous for teachers' professional growth. The article explores the following topics:

1. SFA as a worldview and a methodology of explaining human experience useful for building developmental relations.

2. SFA as an inventory of educational and developmental techniques useful for contemporary classrooms.

3. SFA as an inventory of self-development activities in constructing teachers' life and professional success.

\section{EVIDENCE-BASED FACTS}

Professionalism of the teachers can be approached from different perspectives. It may be seen as an inherent element of the profession rooted in its mission. In this context, professionalism may be treated as an assumed and expected value. Teachers are perceived as highly qualified professionals who have chosen the career due to their great competence regarding education of different age groups: children, teenagers, and adults (Kwiatkowska, 2005; Kwiatkowski, 2012; Michalak, 2007; Watt, Richardson, Tysvaer, 2007; Huberman, 1989). 
Teacher professionalism may be also understood as a set of given attitudes towards all participants of the education process (teachers themselves, students and their parents, as well as other entities), including professional knowledge, skills, and behaviours reflected in positive and creative relations and professional interactions. Finally, teachers' professionalism may be seen as a space for their professional growth that relates to development and mastering the profession (Snoek, 2009; Jazukiewicz, 2017). When discussing teacher professionalism, Snoek (2009) offered a synthetic outline of its constitutive features. According to him, teacher professionalism covers the following dimensions:

- "Knowledge:

- Thorough knowledge of the subject

- Thorough knowledge of the teaching and learning process (including being up to date with relevant outcomes of educational research)

- Thorough knowledge of society

- Knowledge of policy and organisation in education

- Skills:

- Able to communicate and discuss educational issues with a wider audience

- Able to account the quality of work to the outside world

- Able to conduct research within the practice of schools

- Able to contribute to collaborative learning of professional communities

- Able to translate outcomes of educational research to innovations in the classroom/school

- Attitudes

- Dedicated to the learning of pupils

- Committed to the profession and the collective group of professionals

- Willing to contribute to the collective knowledge of the profession

- Committed to the ethical code of the profession and the integrity of his/ her work

- Willing to account the quality of work to the outside world

- Focused on continuous professional development

- Focused on improvement and innovation of teaching" (Snoek, 2009, p. 9).

Teachers acquire professional competence in various ways, mostly through formal education that allows them to gain necessary qualification. Then, teachers continue to develop their knowledge and gain new skills in more specialized areas through postgraduate studies and courses. Finally, teachers' professionalism is shaped by their involvement in broadly understood professional development.

Teachers' acquisition of personal and professional competence may be supported by the inclusion of the solution-focused approach into the university curricula and teacher training. This chapter aims to present SFA philosophy and 
explore its implications to the growth of teachers' professionalism, irrespective of its national or international contexts. The article unveils how to use SFA to make it advantageous for teachers' professional growth.

The article includes the following topics:

1. SFA as a worldview and a methodology of explaining human experience useful for building developmental relations,

2. SFA as an inventory of educational and developmental techniques useful for contemporary classrooms,

3. SFA as an inventory of self-development activities in constructing teachers' life and professional success.

\section{SFA AS A WORLDVIEW AND A METHODOLOGY OF EXPLAINING HUMAN EXPERIENCE USEFUL FOR BUILDING DEVELOPMENTAL RELATIONS}

SFA-based education and support activities rely on a vast array of techniques and tools of communicating with clients/students. The primary function of all SFA tools is to empower a person to build solutions to their problems. SFA philosophy is best expressed in the following three principles:

1 . If it works, do more of it.

2. If it doesn't work, do something else.

3. If it isn't broken, don't fix it.

4. The SFA experts working with the Warsaw-based SFA Centre add one more: Don't complicate. Life is really simple (CTSR. Podstawowe...).

The above assumptions may seem obvious, yet when facing a crisis connected with a given problem, people often experience difficulties with finding solutions, they hardly use their previous experiences, or they repeat an ineffective sequence of decisions and actions but they hope for a different, positive outcome. Szczepkowski (2007) accurately concludes that most people mistakenly believe that if a problem is serious and complicated, the solution to this problem is also complicated and difficult to implement. It may seem logical, but it is not always true.

SFA was created in the 1970s at the Brief Family Therapy Centre in Milwaukee as an alternative to traditional trends in therapy used in psychotherapy and social work. It has been created by Steve de Shazer and Insoo Kim Berg who promoted a form of therapy that focuses on the client's resources and goals, not deficiencies and problems.

The main aim of the solution-focused [brief] therapy is looking for solutions in the preferred/desired future, which allows one to find solutions to a present problem (it is almost a side effect) (de Jong, Berg, 2007). 
The creators of the Solution-Focused Therapy Centre in Warsaw emphasize that the SFA rules are connected solely with the techniques of supporting change and ways of its effective implementation. Instead of producing theories on what should the situation be like and why it is not the way it should be, SFA focuses on what is effective and what helps in a given situation, while it also attempts to apply those methods to other fields and moments of the client's life (CTSR. Centrum...).

The main assumptions and techniques concerning the solution-focused approach have been broadly discussed in numerous publications written by the creators and practitioners of SFA (de Shazer, 1984, 1985, 1992; Proudlock, 2017; de Shazer et al., 2007; de Jong, Berg, 2007; Berg, de Shazer, 1993; Berg, Dolan, 2001; Franklin, Bolton, 2014; Burg, Mayhall, 2002; Pichot, Dolan, 2003) and they can be summarized as follows:

1. Clients [students/parents] are experts on their own lives. They set goals, define the methods of its achievement, and assess them. They have tools (even if they cannot see them at a given moment) to find solutions to a given situation. The level of the individual's autonomy - the basic element in the SFA - depends on the development age of the person the teacher is working with. This "expert" quality will manifest itself differently in children and in adults. While working with children and teenagers, the solutionfocused philosophy translates into the development of self-awareness, self-reflexivity, decision-making skills, understanding one's own needs, and setting constructive goals, as well as the awareness of the cause-andeffect relationship between decisions, actions and consequences; in other words - developing the sense of responsibility for students' own lives.

2. Teacher/Counsellor/Therapist is not an "expert" regarding the client's needs and the solutions they need to find in order to achieve the goal. They do not set the goals, unlike in traditional psychotherapy. The goal of the therapy/consultation is established by the client, because only he or she knows what is important to them and what they need. At this point it is necessary to explain the difference between the aim and idea.

3. In education and counselling, students often set goals such as winning a marathon, while in fact it is only an idea that leads to the achievement of another, real goal - namely improving one's self-esteem, feeling better in their body, gaining more independence through improvement of one's health, proving themselves, gaining admiration or acceptance of a group, etc.

4. Teacher/Counsellor/Therapist assumes the "not-knowing" position. "Notknowing" means that it is the client who has the knowledge about their lives and their world. The teacher uncovers this knowledge and gets to know the student/parent. This "not-knowing" approach concerns solu- 
tions as well, also in counselling. It is the client who looks for solutions and assesses their value and applicability.

5. Perceiving students' parents as resourceful and as experts on their own situation improves the mutual understanding and cooperation. On the one hand, the teacher finds him/herself in a comfortable situation in which he/ she does not need to know (although it is often expected of them to have and offer ready-made solutions). If these are the parents who know the situation and solutions, then they also have the agency and, hence, they assume responsibility for their own decisions. On the other, the lack of knowledge allows the teachers to reduce, or even eliminate, the elements of judgment about the parents' decision/behaviours/attitudes that may sometimes negatively affect the relationship. Parents often feel helpless and guilty when they experience upbringing difficulties; they are afraid of being criticized by the teacher and, consequently, often become defensive, which, in turn, prevents them from focusing on the goal. The teacher who follows SFA principles assumes that the parents are positive and involved, they care about the well-being of their children, they strive to achieve positive goals, and they encounter difficulties because they have chosen ineffective tools. Moreover, the teacher is also convinced that each parent, regardless of their current difficult situation, has certain experience in dealing with the problem, hence they have the resources necessary to reach a given goal.

6. Focus on building solutions and not solving problems. It often happens that people concentrate their efforts on solving current problems, which brings about short-term change. Building solutions is different since it implies that a person implements new strategies so as to avoid similar problems in the future. Counselling could therefore lead to mobilization of resources in order to find solutions, that is to shape one's life in a desired way. Instead of producing theories on what should the situation be like and why it is not, SFA focuses on what is effective and helps, and attempts to apply the solutions to other fields and moments of the client's life (CTSR. Podstawowe...).

7. Goal helps in building solutions; it is based on the client's preferred/desired future. Focusing on the preferred/desired future is crucial not only as far as the teachers' approach to work is concerned, but also regarding the relations with their students. It refers to individual's vision of their desired life. Desired future defines the goals; therefore, the goal is not to find a solution to a given problem, but to achieve something, to develop a competence that brings one closer to the preferred future. It means that clients will start to notice more and more elements of the desired future in their lives. 
8. Focus on the future - solutions are found in the future, not in the present day or in the past. The experienced difficulties and problems do not belong to the desired future, or to the desired condition, therefore, focusing on them does not bring the client closer to the desired goal.

9. Brief therapeutic contact - focus on the achievement of the therapy's goal in the shortest possible time.

10. Focus on what is realistic from the client's perspective. This assumption is crucial when working with students' parents. It assumes that there are no objectively good/best solutions. The best solution is the one whose implementation, from the teacher's/parent's/student's subjective perspective, is realistic. Only a given person, the agent, the expert on one's own life, can assess if a given activity is workable or not under the circumstances. The selection of actions that are possible to be implemented allows this person to achieve success (even small).

11. Building solutions = "staying on the bright side of life". This metaphor means keeping in touch with reality but focusing on its positive, not negative, aspects. Both teachers and students or their parents focus on the desired future that offers solutions, on the resources, achievements, possibilities and ways to deal with the problem, both the old and new ways (own and other students or parents).

Summing up, SFA-oriented teachers approach themselves and others from a certain perspective. They see their students, students' parents, co-workers and themselves as people who:

- are experts on their own lives - they know what is important to them, what is of the utmost importance, what direction they want to go into, they know their aspirations, as well as what they want to achieve and how to achieve it;

- make decisions concerning themselves, their goals and actions;

- are rich in resources. They have tools they can use to change their situation and achieve desired goals (Klimkowska, 2018; De Jong, Berg, 2007; Świtek, 2014a, 2014b; Krasiejko, 2009).

As a result of implementing SFA, the teachers can:

- focus on the students' resources, not their limitations, mistakes or faults;

- develop their students' ability to establish goals, look for solutions, build solutions, and, at the same time, they strengthen their independence and help them assume responsibility for their own life;

- help their students focus on what helps in achieving a goal, not on a problem and its cause, or on looking for the culprit of a given situation;

- develop in students the sense of one's self-esteem, agency, and control over their lives, as well as proactive behaviours and hope. 


\section{SFA AS AN INVENTORY OF EDUCATIONAL AND DEVELOPMENTAL TECHNIQUES USEFUL FOR CONTEMPORARY CLASSROOMS}

What is characteristic of all educational and counselling activities in the SFA is the focus on the solutions and preferred/desired future, not on the problem that made the teacher act or made the student ask for help.

The main SFA techniques and tools for education and counselling, apart from the already discussed "not-knowing" approach, include: compliments, miracle questions and looking for preferred/desired future, looking for exceptions and looking for previous solutions, scaling questions, and coping questions. These techniques have been well described in different studies, including Internet publications and websites run by the organizations promoting SFA. This paper will discuss them briefly in the context of the teacher's work with parents and students.

\section{COMPLIMENTS}

Compliments are considered one of the key competences of a SFA teacher/counsellor/therapist. They can be described as the teacher's internal radar of a kind that detects all, even the slightest, indications of the student's or parent's resources. The aim of this method is to make the client [student/parent] realize, strengthen and develop all resources that may be used to achieve a given goal. "Validating what clients are already doing well, and acknowledging how difficult their problems are encourages the client to change while giving the message that the therapist [teacher] has been listening (i.e., understands) and cares" (Dolan, n.d.). Compliments can be expressed in questions such as "How did you do that?" that invite the client to self-compliment by virtue of answering the question" (Dolan, n.d.).

Kosman (2013) emphasizes that complimenting, as a type of feedback concerning the clients' [student's/parent's] resources observed by the teacher/counsellor, should be expressed in the form of skills and possibilities (e.g., you can, you are able to, you know how to) and not as features "you are"; such a form facilitates the acceptance and implementation of the information. It should be based on observations and information delivered by client through his words or processes, as this would make the teacher's feedback more reliable and not seen as a pleasantry. This technique is extensively discussed in Thomas (2016). 
$\mathrm{MQ}$ is one of the most unique and popular SFA techniques. Its aim is to envision one's desired future and describe in detail the image of one's life without the problem one is experiencing. The miracle questions may be used both in the case of reversible problems, namely those that can be dealt with, as well as when the problem concerns a permanent loss or limitation. In the former, the client has an opportunity not only to imagine, but to nearly experience the situation in which the problem does not exist anymore, in other words, to experience the desired future. In the second case, the miracle concerns dealing with a problem, although the problem continues to exist in the future (irreversible event, disability, death of a close person, etc).

This technique may be used if the client is able to use their imagination and is able to think in abstract terms (therefore, this technique will not be effective in the case of pre-schoolers and young pupils).

Miracle question may be introduced as follows: Imagine that tonight you go to bed, you have had a normal day and now it is time to rest. A miracle happens at night and all your problems are gone. You, however, are unaware that the miracle has happened. You realize it only when you wake up. How will you be able to tell that the miracle has happened? When the teacher/counsellor attempts to encourage the client to envision such a situation, their role is to direct the client's attention to selected aspects of reality. The questions that might be found helpful include:

- What do you notice first? What is around you? What do you notice later?

- How do you look like? What are you wearing? How do you feel?

- Where are you? Who is with you?

- Is your approach different? Has your behaviour changed?

- How has your environment changed?

- What do others notice (remember that they are also unaware of the miracle)? What do your parents observe? What do your children notice? What do your spouse notice?

In the miracle questions technique, it is important that the client offers as many details as possible, that is that they imagine their desired future/reality in every detail. The miracle questions technique may be used in different ways; the two main ones concern looking for a miracle in the client's [student's/parent's] current situation or searching for solutions that would enable the client to experience a miracle and make the elements of miracle become more frequent in the client's life.

Labuda (2007) emphasizes that the miracle questions technique allows the therapist [teacher/counsellor] to elicit from the client the image of their preferred/ desired reality that concerns them and their surroundings: family, relatives, the 
spouse, etc. The questions uncover the vision of the client's desired life. It is important for the description to contain measurable and behavioural events that took place on a given day.

\section{LOOKING FOR EXCEPTIONS (EXCEPTION QUESTIONS) AND LOOKING FOR PREVIOUS SOLUTIONS}

These two areas stem from the SFA teacher's/counsellor's belief that most people have resolved problems in the past and, hence, they have some ideas about how they could approach a given problem now. However, when they are stressed, they tend to overlook that knowledge. In such a situation, questions like: "Are there times when this has been less of a problem?" or "What did you (or others) do that was helpful?" (Dolan, n.d.) might be helpful.

As explained by Dolan:

Even when a client does not have a previous solution that can be repeated, most have recent examples of exceptions to their problem. These are times when a problem could occur, but does not. The difference between a previous solution and an exception is small, but significant. A previous solution is something that the family has tried on their own that has worked, but later discontinued. An exception is something that happens instead of the problem, often spontaneously and without conscious intention. SF therapists may help clients identify these exceptions by asking, "What is different about the times when this is less of a problem? (Dolan, n.d.)

The aim of this question is to offer the client - student/parent - an opportunity to notice that the way people perceive problems can change. Sometimes a person can perceive a problem as more or less grave, which suggests that there are exceptions. Secondly, it draws the student's attention to those exceptions to the behaviours/thoughts/actions that "work", that is to the ways to deal with a certain aspect/scope of the problem. SFA practitioners underline the importance of the following questions when looking for exceptions: "What's different about those times?; What do you do differently?; Who else is involved, or notices these differences?; How could more of that happen?; How do you explain these differences?; How did you get that to happen?" (Rhodes, Ajmal, 1995, p. 13). 


\section{SCALING QUESTIONS (SQ)}

SQ method may be used by teachers to evaluate their client's current situation. This technique may be used by students/parents to assess their condition/wellbeing/progress towards the goal at a given time, as well as to define the next small realistic step that would bring them closer to their goal. Dolan explains:

Scaling questions (SQ) can be used when there is not enough time to use the MQ and it is also useful in helping clients to assess their own situations, track their own progress, or evaluate how others might rate them on a scale of 0 to 10. It is used in many ways, including with children and clients who are not verbal or who have impaired verbal skills. One can ask about clients' motivation, hopefulness, depression, confidence, and progress they made, or a host of other topics that can be used to track their performance and what might be the next small steps. (Dolan, n.d.)

The application of the technique may look as follows: the teacher/counsellor asks the client to assess their current situation regarding the problem on a scale of 1 to 10 , 1 represents the lowest ability to cope with the problem, while 10 means the highest ability to cope; the clients can be asked, for instance, how safe they feel in the classroom or how satisfied they are with their classmate relationships, or how close they are with their children. Then, the counsellor asks additional questions: 1) what have they done and what helped them reach this particular level? and 2) what could they do to move up on the problem's gravity scale and to cope better with the problem?

The scaling questions technique allows the counsellor to monitor the client's current condition and changes that take place, as well as help clients plan actions to improve their situation.

\section{COPING QUESTIONS (CQ)}

The aim of CQ is to direct the client's (student's/parent's) attention to the effective ways of coping with the same or similar problem. As highlighted by Dolan:

[t]his question is a powerful reminder that all clients engage in many useful things even in times of overwhelming difficulties. Even in the midst of despair, many clients do manage to get out of bed, get dressed, feed their children, and do many other things that require major effort. Coping questions such as "How have you managed to carry on?" or "How have you managed to prevent things from becoming worse?" open up a different way of looking at client's resiliency and determination. (Dolan, n.d.) 
These questions are particularly useful when working with parents who feel the sense of failure regarding the relationships with the children (they seem they have failed when dealing with the children's resistance, absent-mindedness, inattentiveness, or their ignoring them, etc.) They allow the clients to see how effectively they have already coped with similar situations, although they might not be aware of that.

Summing up, the application of SFA tools allows both teachers and students/ parents to:

- focus on students' and parents' resources,

- help students and parents develop a constructive and precise vision of their desired future,

- help students and parents develop skills to notice the elements of the desired future in their current situation,

- help students and parents focus on what supports the achievement of a given goal, rather than on the problem or its cause.

Specific situations and contexts in which a variety of SFA tools are applicable can be found in the following guidebooks: Solution-Focused Practice - a Toolkit for Children \& Young People, edited by Bazalgette and collaborators (2014), offers some ready-made exercises that could be used when working with the clients; and The Advisor's Toolbox. Techniques and Interventions of Solution-Focused Advising edited by Burg, and Mayhall (2002) that offers a compilation of SFA tools.

Concrete proposals for the application of SFA in the work of teachers, counsellors and therapists can also be found in the publications by the Institute for Solution-Focused Therapy (https://solutionfocused.net/). The Institute website includes Inspirations Newsletter (https://solutionfocused.net/insp-newsletter/), offering reflection and practice-oriented content published by leading specialists in SFA. From the teacher's perspective, of special interest can be the following: Trepper and Dolan (2017), and Bodmer Lutz (2018, 2019), .

To illustrate the way of employing SFA in student counselling, let us imagine a student who has a problem with piling negative grades. Under SFA, the question that a counsellor can ask is not why he or she has negative grades, but what he or she would like to function in the school context. Changing the perspective, the counsellor shifts the focus from short-term problems of the student to his or her desired future. The counsellor then checks with the student what elements of the desired future are already present in his or her life. Then the student examines which activities increase the number of the desired future elements in their life (according to SFA, if something works, do more of it). The next step is for the student to determine which actions are not effective and to look for other options 
that are likely to bring the expected results (according to SFA, if something does not work, do something else).

\section{SFA AS AN INVENTORY OF SELF-DEVELOPMENT ACTIVITIES IN CONSTRUCTING TEACHERS' LIFE AND PROFESSIONAL SUCCESS}

The last part of this chapter focuses on opportunities for the effective use of SFA as self-development activities for teachers. The already discussed SFA tools may be effectively used by teachers in self-coaching and management of one's own professional development. They may be found particularly useful in:

- defining one's professional and personal goals based on the desired future,

- reflecting on one's own goals and current situation - focusing on what proves effective and supports one in achieving their goal instead of focusing on what the situation should be like and why it is not.

SFA may prove particularly useful in planning one's own professional development and mastering one's profession. A detailed description of the preferred future seems to be of key importance. It allows the teacher to define the elements of the future that are found in his current job, the frequency of their occurrence, and the circumstances that support them. Moreover, with the use of the scaling questions technique, the teacher may asses their level of progress regarding their goals or problem management, recognize the resources that helped them reach a given level and decide on the next small step to be taken in order to achieve their goal.

SFA techniques are useful at every stage of the teachers' professional development cycle - they may help teachers at the beginning of their carer as well as might be found effective by those experienced, highly professional teachers who may feel exhausted after many years of teaching or may be in danger of burnout.

Examples of use of different scaling questions techniques can be found in Dolan (2019), including: the "In a Great Mood" Scale, the Instead Scale and the Optimal Self-Care scale.

\section{SUMMARY}

SFA has wide applications in both psychotherapy and education. The SFA philosophy creates an educational environment that is conducive to the development of students and teachers. SFA tools are quite simple to learn. As such, they can be successfully incorporated into the repertoire of educational interventions of both experienced and novice teachers. 
The SFA-based attitude towards oneself as well as students and their parents may be developed during university education as well as during specialized courses. The inclusion of the solution-focused approach into the university curricula and teacher training tailored to the needs of a given programme would allow young adults adopt the attitude of "staying on the bright side of life", and spark their interest in the world and in others, focus on one's own and other's resources, abilities, individuality, and uniqueness. This genuine interest in the "uniqueness" of other people's world is shaped through the development of the "not-knowing" approach in teachers and helps them strengthen motivation to pursue teaching career and derive pleasure from it, and, at the same time, reduce the feeling of being burdened with parents/students, their problems, as well as of responsibility for changes in their lives.

SFA is particularly advantageous for students with a wide range of difficulties, disorders or dysfunctions. Often, the teacher, by definition, is the person who knows what is wrong with the child, with the family, knows their needs and knows what is best for them, as well as what they should do to achieve it. Such a lens makes it difficult not only to notice, but to think that a mother facing upbringing difficulties with a child who "constantly causes problems in our school" may have resources, may be good at something, may be able to deal with certain problems or have dealt with them in the past. The SFA-based relationship between the student/parent and teacher focuses exactly on these hidden resources.

A solution-focused approach enhances the professional competence of teachers as they work with different groups, from children to elderly people, and in various capacities - as educators, teachers, counsellors, and therapists.

The author of this article is well aware that it does not exhaust the topic, and the discussion on the SFA principles may seem insufficient. However, the aim of this article was to introduce the solution-focused approach, to show the benefits of its application in education, upbringing and teacher's development, and consequently, to encourage the Readers to explore SFA in depth and put it in practice.

\section{REFERENCES}

Bazalgette, L., Emilsson, M., Breslin, S., Modder, A., Clunas, M., Brown A., Anderson, N. (2014). Solution-Focused Practice - a Toolkit for Children \& Young People. NSPCC. Retrieved from: http://www.socialworkerstoolbox.com/solution-focused-practice-a-toolkit-for-working-with-children-and-young-people/

Berg, I.K., de Shazer, S. (1993). Making Numbers Talk: Language in Therapy. In: S. Friedman (ed.). The New Language of Change: Constructive Collaboration in Psychotherapy (pp. 5-24). New York: Guilford Press. 
Berg, I.K., Dolan, Y. (2001). Tales of Solution: A Collection of Hope Inspiring Stories. New York: W.W. Norton.

Bodmer Lutz, A. (2018). A Language of Hope: The Top Ten Solution-Focused Translations. The Institute for Solution-Focused Therapy. Retrieved from: https://solutionfocused.net/2018/02/10/language-hope-solution-focused-therapy-translations-enhance-engagement/

Bodmer Lutz, A. (2019). Cope Is One Letter Away from Hope: Solution-Focused Safety Assessment (SFSA). The Institute for Solution-Focused Therapy. Retrieved from: https://solutionfocused.net/2019/05/03/cope-is-one-letter-away-from-hope-solution-focused-safety-assessment-sfsa/

Burg, J.E., Mayhall, J.L. (2002). The Advisor's Toolbox. Techniques and Interventions of Solution-Focused Advising. NACADA Journal, 22(2) Fall.

CTSR. Centrum Terapii Skoncentrowanej Na Rozwiązaniach. Retrieved from: www. ctsr.pl

CTSR. Podstawowe założenia TSR. Retrieved from: http://www.ctsr.pl/podstawowe-zalozenia-tsr

De Jong, P., Berg, I.K. (2007). Interviewing for Solutions (3 ${ }^{\text {rd }}$ ed.). Brooks/Cole: Pacific Grove.

De Shazer, S. (1984). The Death of Resistance. Family Process, 23(1), 11-21.

De Shazer, S. (1985). Keys to Solution in Brief Therapy. New York: Norton.

De Shazer, S. (1992). Patterns of Brief Family Therapy. New York: Guilford.

De Shazer, S., Dolan, Y., Korman, H., McCollum, E., Trepper, T., \& Berg, I. K. (2007). Haworth Brief Therapy Series. More Than Miracles: The State of the Art of Solution-Focused Brief Therapy. New York: Haworth Press.

Dolan, Y. (2019). 3 Solution-Focused Self-Help Scales for Mood Enhancement. The Institute for Solution-Focused Therapy. Retrieved from: https://solutionfocused. net/2019/05/03/3-solution-focused-self-help-scales-for-mood-enhancement/

Dolan, Y. (n.d.). What Is Solution-Focused Therapy? The Institute for Solution-Focused Therapy. Retrieved from: https://solutionfocused.net/what-is-solution-focused-therapy/

Franklin, C., Bolton, K.W. (2014). Solution-Focused Brief Therapy. In: R.H. Witte. G.S. Mosley-Howard (eds.). Mental Health Practice in Today's Schools. Issues and Interventions (pp. 145-168). New York: Springer Publishing Company.

Huberman, M. (1989). The Professional Life Cycle of Teachers. Teachers College Record, 91(1), 31-57.

Jazukiewicz, I. (2017). Wymiary profesjonalizmu współczesnego nauczyciela. Problemy Profesjologii, 2, 57-68.

Klimkowska, K. (2018). Zastosowanie podejścia skoncentrowanego na rozwiązaniach we wzmacnianiu stanu Ja-Dorosłego. Edukacyjna Analiza Transakcyjna, 7, 85-98. 
Kosman, T. (2013). Założenia terapii skoncentrowanej na rozwiązaniach (TSR). Warmińsko-Mazurski Kwartalnik Naukowy Nauki Społeczne, 1, 9-26.

Krasiejko, I. (2009). Podejście Skoncentrowane na Rozwiązaniach w edukacji. Podstawy Edukacji, 2, 267-288.

Kwiatkowska, H. (2005). Tożsamość nauczycieli. Między anomią a autonomią. Gdańsk: GWP.

Kwiatkowski, S. (2012). Choosing the Teaching Profession - Research Results. In: J. Madalińska-Michalak. H. Niemi. S. Chong (eds.). Research, Policy, and Practice in Teacher Education in Europe (pp. 141-162). Łódź: UŁ.

Labuda, K. (2007). Znaczenie i rola nadziei w terapii uzależnień. Wychowanie na co dzień, 3, 11-14.

Mahlberg, K., Sjoblom, M. (2004). Solution Focused Education. Stockholm: Mareld.

Majchrowska, E., Zubrzycka-Maciąg, T. (2016). Podejście Skoncentrowane na Rozwiązaniach w Edukacji. Rozwiązania, 2, 24-29.

Michalak, J.M. (2007). Uwarunkowania sukcesów zawodowych nauczycieli. Studium przypadków. Łódź: UŁ.

Pichot, T., Dolan, Y. (2003). Solution-Focused Brief Therapy: Its Effective Use in Agency Settings. New York: Haworth.

Proudlock, S. (2017). The Solution Focused Way. Incorporating Solution Focused Therapy Tools and Techniques into Your Everyday Work. London-New York: Routledge.

Rhodes, J., Ajmal, Y. (1995). Solution Focused Thinking in Schools Behaviour, Reading and Organisation. London: BT Press.

Snoek, M. (2009). Theories on and Concepts of Professionalism of Teachers and Their Consequences for the Curriculum in Teacher Education. Retrieved from: http:// www.hva.nl/kenniscentrum-doo/wp-content/

Szczepkowski, J. (2007). Terapia młodzieży z problemem narkotykowym. Podejście Skoncentrowane na Rozwiązaniach. Toruń: Akapit.

Świtek, T. (2014a). Jak pracować z osobami stosującymi przemoc. Centrum Podejścia Skoncentrowanego na Rozwiązaniach. Retrieved form: http://centrumpsrwd.nazwa. pl/instalator/wordpress/wp-content/uploads/2014/07/poradnik_praca_z_osp.pdf

Świtek, T. (2014b). Solution Focused Brief Therapy - na przekór przyzwyczajeniom i schematom. Spotkanie z Insoo Kim Berg z BFTC w Milwaukee. Centrum Podejścia Skoncentrowanego na Rozwiązaniach. Retrieved form: http://centrumpsrwd. nazwa.pl/instalator/wordpress/wp-content/uploads/2014/07/sfbtartykul.pdf

Thomas, F. (2016). Complimenting in Solution-Focused Brief Therapy. Journal of Solution-Focused Brief Therapy, 2(1), 1-22.

Trepper, T.S., Dolan, Y.M. (2017). Solution-Focused Inspirations for the Educator. The Institute for Solution-Focused Therapy. Retrieved from: https://solutionfocused. net/2017/05/06/solution-focused-inspirations-educator/\#_ftn1 
Watt, H., Richardson, P., Tysvaer, N. (2007). Profiles of Beginning Teachers' Professional Engagement and Career Development Aspirations. In: A. Berry. A. Clemans. A. Kostogriz (eds.). Dimensions of Professional Learning: Professionalism, Practice and Identity (pp. 155-176). Rotterdam: Sense Publishers.

Zubrzycka-Maciąg, T. (2019). Podejście Skoncentrowane na Rozwiązaniach w doskonaleniu zawodowym nauczycieli. Edukacja Ustawiczna Dorosłych, 1, 144-153.

\author{
PODEJŚCIE SKONCENTROWANE NA ROZWIĄZANIACH \\ JAKO SPOSÓB WZMACNIANIA PROFESJONALIZMU NAUCZYCIELI
}

Wprowadzenie: Programy rozwoju nauczycieli koncentrują się na osiąganiu kompetencji zawodowych i pedagogicznych, a także na kształtowaniu postaw i kultury zawodowej. Na pracę nauczycieli oraz ich cele osobiste i zawodowe wpływa to, jak postrzegają siebie jako osoby i jako profesjonalistów, a także jak postrzegają swoich uczniów i środowisko nauczania. Cel badań: Celem niniejszego artykułu jest przedstawienie filozofii SFA i ukazanie jej implikacji dla wzrostu profesjonalizmu nauczycieli, niezależnie od kontekstu krajowego czy międzynarodowego. Artykuł ujawnia jak wykorzystywać SFA w różnych obszarach rozwoju zawodowego nauczycieli. W artykule poruszono następujące tematy:

1. SFA jako światopogląd i metodologia wyjaśniania ludzkiego doświadczenia przydatna do budowania relacji rozwojowych.

2. SFA jako zbiór technik edukacyjnych i rozwojowych przydatnych w prowadzeniu zajęć. 3. SFA jako zestaw działań samorozwojowych sprzyjających konstruowaniu sukcesu życiowego i zawodowego nauczycieli.

Stan wiedzy: Do profesjonalizmu nauczycieli podchodzi się z różnych perspektyw - jako do wysoko wykwalifikowanych profesjonalistów, jako do zbioru danych postaw wobec wszystkich uczestników procesu edukacji, czy też jako do przestrzeni rozwoju zawodowego nauczycieli, która odnosi się do rozwoju i mistrzostwa w zawodzie. Głównym celem Podejścia Skoncentrowanego na Rozwiązaniach (SFA) jest poszukiwanie rozwiązań w preferowanej/pożądanej przyszłości, co pozwala na rozwiązanie obecnego problemu.

Podsumowanie: Podejście Skoncentrowane na Rozwiązaniach jest narzędziem, które może być wykorzystywane do wzmacniania nabywanych kompetencji osobistych i zawodowych przez nauczycieli. Może wzbogacić programy nauczania na uniwersytetach i programy doskonalenia nauczycieli.

Słowa kluczowe: profesjonalizm nauczycieli, podejście skoncentrowane na rozwiązaniach, rozwiązywanie problemów 